๑ Entomologica Fennica. 7 September 1995

\title{
Cytotaxonomic characteristics of Chironomus clarus (Diptera, Chironomidae) with completion of the description of morphology of adults and immature stages
}

\author{
Paraskeva Michailova \& Mauri Hirvenoja
}

Michailova, P. \& Hirvenoja, M. 1995: Cytotaxonomic characteristics of Chironomus clarus (Diptera, Chironomidae) with completion of the description of morphology of adults and immature stages. - Entomol. Fennica 6:1928.

The karyotype and external morphology of the larva, pupa and female of Chironomus clarus are described here for the first time. Cytologically $C$. clarus belongs to the thummi complex (chromosome arm combination: $\mathrm{AB}$ $\mathrm{CD}$ EF G). On the basis of external morphology and karyotype this species should be combined with $C$. obtusidens Goetghebuer and $C$. acutiventris Wülker, Ryser \& Scholl in the obtusidens group. C. clarus and C. obtusidens are homosequental sister species (if not even synonyms) with one and the same band sequences. Completions of the male morphology are also given and the species is compared with members of the obtusidens group.

Paraskeva Michailova, Bulgarian Academy of Sciences, Institute of Zoology, 1 Tzar Osvoboditel boulv., Sofia 1000, Bulgaria Mauri Hirvenoja, Sotilaskorventie 13, FIN-01730 Vantaa, Finland

Received 27 January 1994, accepted 8 March 1994

\section{Introduction}

The type locality (near Station 6 in Fig. 10 and Fig. 13 in Hirvenoja 1962b, p. 101) of Chironomus clarus was a small channel between a pond and a small, quite acid (pH 5.4-6.5) littoral lake (sensu Brundin 1956:196) Posolampi in Sodankylä, north Finland. The current of flow in this channel was very slow because neither the pond nor the lake had any outlet; the water soaked into the peat of Posoaapa, which was one of the largest aapa bogs (a subarctic type of sedge-bog) in Finland. The type locality no longer exists as a channel, but was inundated, as well as the other adjacent water habitats, to become part of the large Lokka dam basin (about $40 \mathrm{~km}$ in diameter).

Originally (Hirvenoja 1962a) only one individual of $C$. clarus was described. Two additional male individuals were later found in the original material (1961). It is quite impossible to complete the material from the precise type locality, or (attempts have been made!) from the same area, which is today ecologically totally different. Therefore, new material found quite abundantly in Riihimäki, south Finland, has been used here for the present re-description of $C$. clarus. This material or description lacks, of course, the same nomenclatural significance as the holotype (in the Zoological Museum, Helsinki).

The morphometrical variation of the new 
southern material includes the key characters of the specimens from north Finland. The adults reared in June-July 1988 in south Finland at an exceptionally high room temperature represent the smallest measured individuals, and the freeliving individuals from north Finland are the largest. The most important difference between the illustration of the hypopygium in Hirvenoja (1962a: Fig 1) and in the present paper (Fig. 3) is the peculiar shape of appendage 1 in the previous figure, which is a function of the mounting position. Appendage 1 in the old microscope-slide of the holotype in question has, however, moved later to the more "normal"position, seen in the present paper's illustration.

\section{Karyological studies}

Material: 12 larvae; 19.9.1986, 22.6.1988 and 7.6.1990 (M.H. leg.) from Hirvenoja, Riihimäki, south Finland.

Methods: Larvae fixed in alcohol:acetic acid were used. Chromosome preparations were made from salivary glands according to the aceto-orcein method adopted. The chromosome arms have been letter-indexed from A to $G$, using the sections homologous to $C$. piger Strenzke according to Keyl (1962). A, E, F arms were divided along the arms according to the range of designations proposed by Keyl (1962). B, C, D and G have been divided conditionally by us. Permanent mounts were made using liquid nitrogen. After freezing in liquid nitrogen the preparations were dehydrated in alcohol, rinsed in xylol and mounted in Canadabalsam.

The specimen from which the salivary glands were squashed was treated in $10 \% \mathrm{KOH}$ and mounted on the slide beside the squashed preparation.

Karyotype $2 n=8$. This species belongs to the thummi complex (Keyl 1962) having the arm combination: AB CD EF G. The polytene chromosomes have no clearly marked centromere regions. 1 st and 2nd chromosomes metacentric; 3rd submetacentric and 4th acrocentric (Fig. 1-2). Sex chromosomes were not discovered. It has a nucleolus and a Balbiani ring in 4th (G) chromosome. Inversion polymorphism has not been observed.

Arm A (Fig. 1ab). It is divided into $19 \mathrm{sec}-$ tions. It is almost identical with $C$. obtusidens (Keyl 1960,1962; Petrova \& Michailova 1986) with band sequences: 1ae 7-4 1fk 2ac 10-12 3 if 89 2dk 3 15-13 161719 . The bands are much thinner. Sections $8917-18-19$ are functionally active. The bands in sections $2-3-15-13-16$ were characteristic for this arm. The narrowing in sections 7-4 (Fig. 1ab) is a marker of this arm, which is a part of the basic pattern in the genus Chironomus (sensu Wuilker 1980).

Arm B (Fig. 1ab). It is divided conditionally into 12 sections. The band sequences almost coincide with those of C. obtusidens (Keyl 1960; Wülker et al. 1983; Petrova \& Michailova 1986). The dark band in section 1 is a marker for this arm. Section $3-4-7$ is functionally active. The band pattern in sections $9-10-11$ is distinctive. The band pattern in sections $3-4$ is similar to bands in sections 17-18 of C. plumosus (Linnaeus) (Maximova 1976, Kiknadze 1987, Michailova 1989). The bands of this arm are thinner than those of $C$. obtusidens.

Arm C (Fig. 1cd). It is divided into $11 \mathrm{sec}$ tions. Arm $\mathrm{C}$ begins with light bands, section 1 . Typical is the constriction in section 2 (Fig. 1cd). This feature is a typical sign for the species of the thummi complex. The bands in section 3-45-6 are dark. Sections 9-10 were functionally active. The bands in sections 3-4-5-6 are markers for this arm. Band sequences: $1-5$ are similar to those of $C$. acutiventris 11 (Wülker et al. 1983; Petrova \& Michailova 1986). All bands are thinner than those of $C$. obtusidens.

Arm D. (Fig. 1cd). It is divided conditionally into 12 sections. The arm is characterized by bands in sections 7-8-9-10-11-12. The bands in sections 20-21 are similar to those in sections 6-7 of species from the plumosus group. In section 4 there is a "bulb"-like formation. The band sequence is almost identical to those of $C$. obtusidens (Keyl 1960, Wülker et al. 1983, Petrova \& Michailova 1986).

Arm E (Fig. $2 \mathrm{abc}$ ). It is divided into $13 \mathrm{sec}-$ tions. This arm has band sequences: $123 \mathrm{a} 11 \mathrm{ba}$ $10 \mathrm{cg}$ '3-4 10ba 987653 eb 11 ed 1213 . The band sequence is identical to those of C. obtusidens (Keyl 1962). It is distinguished from C. aberratus Keyl by homozygous inversion (Keyl 1962). 
Arm F (Fig. 2abc). It is similar to C. obtusidens (Keyl 1960, 1962; Wülker et al. 1983; Petrova \& Michailova 1986). The bands are: 19-2 17-1413111819 ac $1019 \mathrm{~d} 20$.

Arm G (Fig. 2d). It is divided into 5 sections. It has a nucleolus and a Balbiani ring, and always is paired. At the region of the nucleolus is a "heterochromatic dark knob".

\section{Morphological studies}

Material and methods: For the re-description, material (M.H. leg.) is available as mentioned below, but used (mounted in Euparal) to a limited extent in the measurements as mentioned (N) in the text.

1) Holotype, male (Zoological Museum, Helsinki) and 2 other males June, 1961, Posolampi, Korvanen, Sodanky]ä, north Finland.

2) Numerous adults, pupal skins and larvae 19811988 from the brook Hirvenoja, a few specimens from the river Punkanjoki and one male with pupal exuviae 1962 from a clay pond; all these in Riihimäki, south Finland.

\subsection{Male}

Wings 4.1 (2.9-4.6) $\mathrm{mm}$. AR (antennal ratio, $\mathrm{N}=8$ ) $3.83(3.50-4.10)$. Palps $(2-5, \mathrm{~N}=8)$ in $\mu \mathrm{m}: 70-80$, 280-300, 280-300, 315-390. LR (leg ratio): $\mathrm{P} 1(\mathrm{~N}=$ 15) $1.43(1.32-1.56), \mathrm{P}_{2}(\mathrm{~N}=8) 0.58(0.57-0.59)$, $\mathrm{P}_{3}(\mathrm{~N}=8) 0.73(0.68-0.77)$. Number $(\mathrm{N}=8)$ of sensilla chaetica: (distally in) $\mathrm{P}_{2} / \mathrm{Ta}_{1} 12.3(7-17), \mathrm{P}_{3} /$ $\mathrm{Ta}_{1}$ 11. (8-18). BR (tarsal beard ratio, $\left.\mathrm{N}=8\right)$ : $\mathrm{P}_{1}$ 2.2(1.9-2.4), $\mathrm{P}_{2}$ 2.5(1.7-3.6), $\mathrm{P}_{3} 4.1$ (2.9-5.9). Legs $\left(\mathrm{P}_{1}-\mathrm{P}_{3}, \mathrm{~N}=8\right)$ in $\mu \mathrm{m}$ :

$\begin{array}{lrrr} & \text { Fore leg } & \text { Mid leg } & \text { Hind leg } \\ \text { Femur } & 1150-1750 & 1250-1830 & 1450-2060 \\ \text { Tibia } & 1050-1650 & 1140-1740 & 1400-2130 \\ \text { Tarsus1 } & 1640-2390 & 670-1000 & 1080-1550 \\ \text { Tarsus2 } & 850-1280 & 400-640 & 610-930 \\ \text { Tarsus3 } & 620-910 & 300-450 & 420-660 \\ \text { Tarsus4 } & 550-760 & 170-300 & 250-390 \\ \text { Tarsus5 } & 250-360 & 140-200 & 120-230\end{array}$

Hypopygium as in Fig. 3. Processus analis apically always rounded, width $(\mathrm{N}=10)$ proximally $<88.3(60-100) \mu \mathrm{m}$; width of anal point / width of appendage $1>3.0$ (cf. Lindeberg \& Wiederholm 1979).

\subsection{Female}

Coloration similar to the male, which is relatively pale (Hirvenoja 1962, Fig. 1). Wing $(\mathrm{N}=6)$ 4.0(3.04.9) $\mathrm{mm}$. Palps $(2-4, \mathrm{~N}=6)$ in $\mu \mathrm{m}: 60-90,190$ $300,200-340,310-420$. LR : $\mathrm{P}_{1}(\mathrm{~N}=13) 1.56$ (1.45-1.67), $\mathrm{P}_{2}(\mathrm{~N}=6) 0.53(0.47-0.56), \mathrm{P}_{3}(\mathrm{~N}=6)$ $0.69(0.67-0.71)$. Number $(\mathrm{N}=6)$ of sensilla chaetica: $\mathrm{P}_{2} / \mathrm{Ta}_{1} 94.0$ (87-102), $\mathrm{P}_{3} / \mathrm{Ta}_{1} 107.3(100$ 112). $\mathrm{BR}(\mathrm{N}=6)$ : $\mathrm{P}_{1} 1.7(1.4-1.9), \mathrm{P}_{2} 1.9(1.2-2.3)$, $\mathrm{P}_{3}$ 2.5(2.0-3.7). Legs $\left(\mathrm{P}_{1}-\mathrm{P}_{3}, \mathrm{~N}=8\right)$ in $\mu \mathrm{m}$ :

$\begin{array}{lrrr} & \text { Fore leg } & \text { Mid leg } & \text { Hind leg } \\ \text { Femur } & 1200-2100 & 1300-2100 & 1300-2260 \\ \text { Tibia } & 1000-1650 & 1240-2050 & 1410-2400 \\ \text { Tarsus1 } & 1610-2660 & 650-1060 & 970-1600 \\ \text { Tarsus2 } & 800-1480 & 390-650 & 600-980 \\ \text { Tarsus3 } & 620-1200 & 290-450 & 490-710 \\ \text { Tarsus4 } & 550-1100 & 190-300 & 290-420 \\ \text { Tarsus5 } & 260-450 & 150-190 & 150-220\end{array}$

Spermathecae oval, 157.7(120-170) $\mu \mathrm{m}$ long.

\subsection{Pupa}

Exuviae 9.5-10.5 mm long, abdomen quite pale. Frontal apotome with cephalic tubercles about $150 \mu \mathrm{m}$ long and up to $110 \mu \mathrm{m}$ broad, each with an apical seta. Thorax dorsally darkened and granulated to the base of the wing sheaths. Basal ring usually about $180 \times 80 \mu \mathrm{m}$, its tracheal patch with $<11-17$ tracheoles across $(\mathrm{N}=7)$, about 3 $\mu \mathrm{m}$ in diameter.

Shagreen on tergites 2-8 typical of the genus, on tergites (2)3-6 somewhat in the $\mathrm{X}$ form, extending laterally not over the most lateral anterior adhesion marks (Langton 1994; "Fensterflecken"Thienemann 1944, "Muskelmale"Fittkau 1962) at this level; on segments 5 and 6 spinules on paratergites (lateral to the row of the lateral adhesion marks). On segment 2 quite large pedes spurii and 94.3(87-101) hooklets $(\mathrm{N}=8)$, the latter mostly with some minute posterior or dorsal denticles: other intersegmental short rows of orally directed spinules present close behind the armament of tergites 4 and 5 ; because the number of the intersegmental spinules is relatively small, the first impression may be that all are lacking (in comparison for instance with C.riparius Meigen).

Some 10-20 $\mu \mathrm{m}$ long points difficult to find on the pleural region, ventral to the lateral setae 
22 Mihailova \& Hirvenoja: Cytotaxonomics of Chironomusclarus• ENTOMOL. FENNICA Vol.6
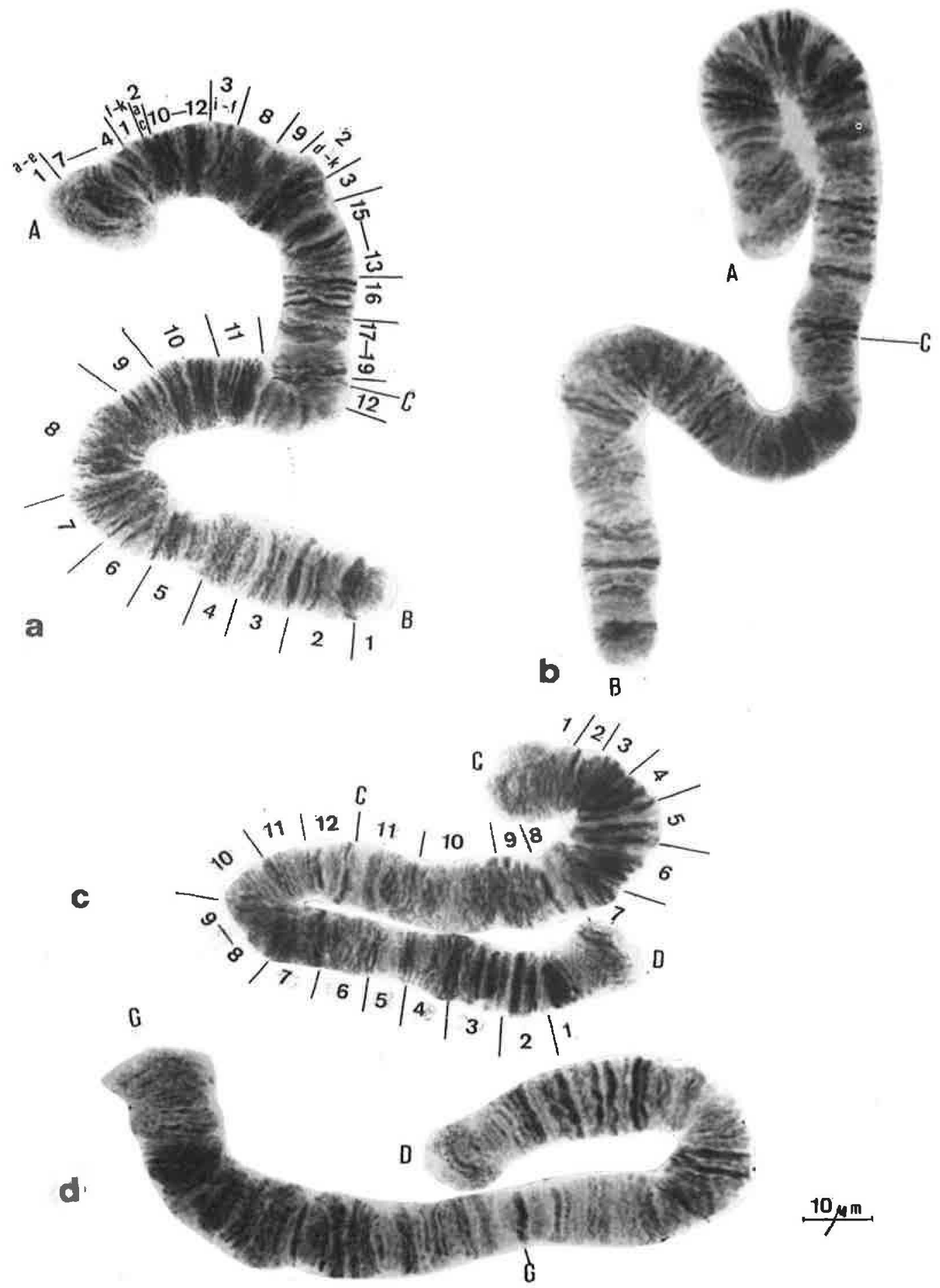

Fig. 1. Chironomus clarus Hirvenoja. a \& b: Chromosome AB; c \& d: Chromosome CD. 


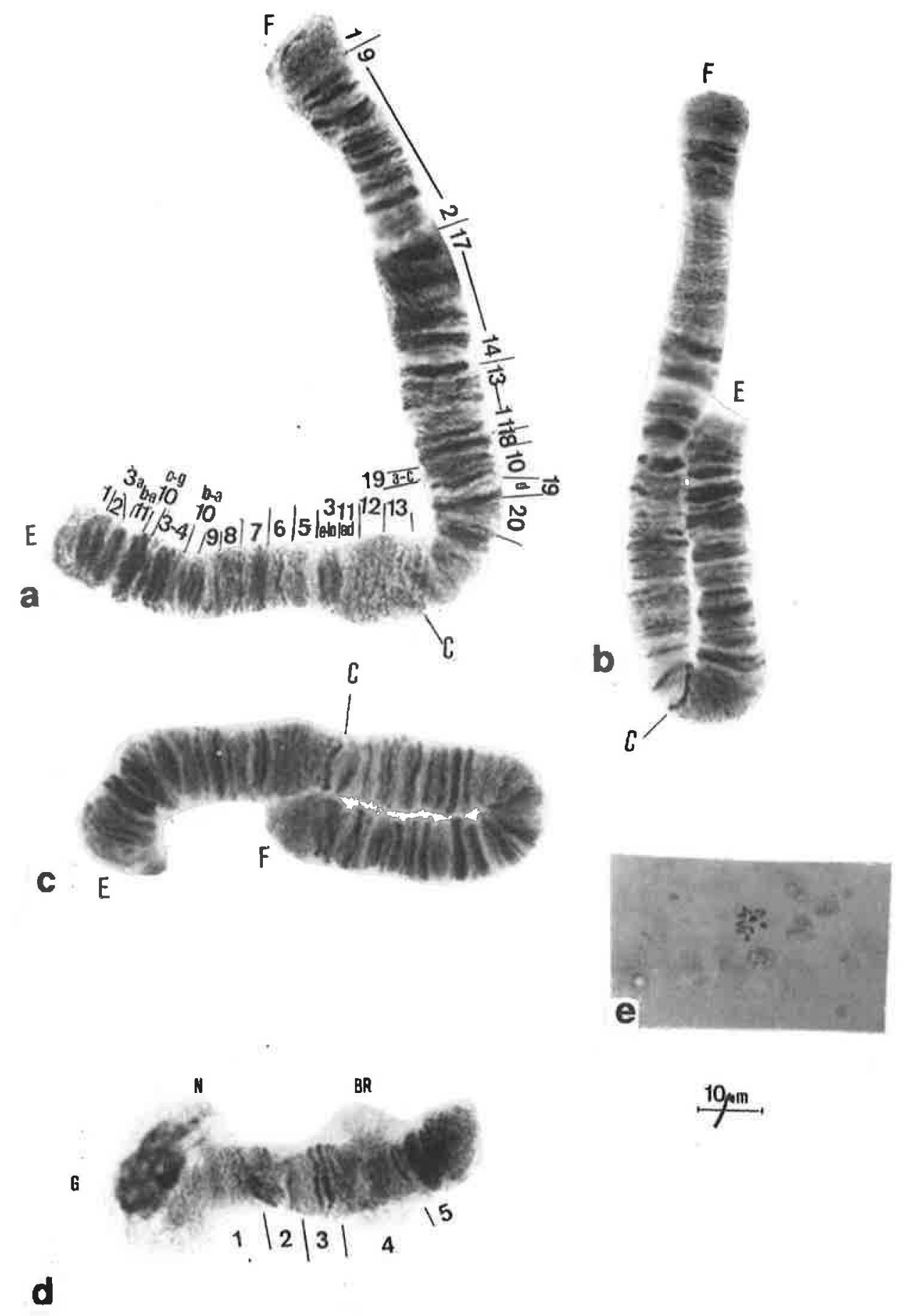

Fig. 2. Chironomus clarus Hirvenoja. a, b \& c: Chromosome EF; d: Chromosome G; e: Metaphase plate. —The scale does not apply to e. 


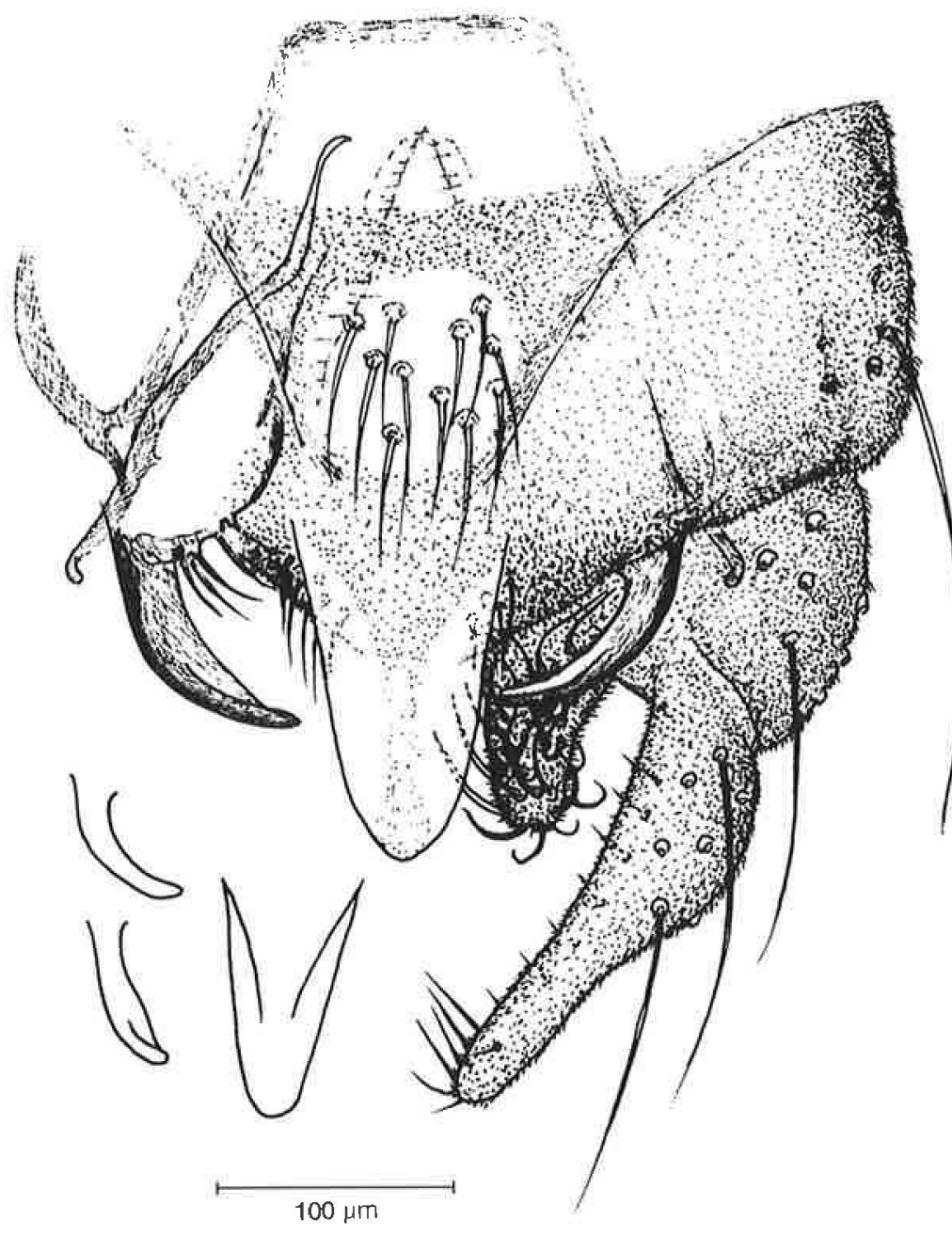

Fig. 3. Chironomus clarus Hirvenoja. Male hypopygium from the Riihimäki population with variation in appendage 1 and processus analis. on segment 4. Anal-lateral to sternite1 are a few spinules in some exuviae. Lateral and medial longitudinal rows of spinules on sternite 2 clearly separated from each other, parasternite (?) also chagreened; longitudinal lateral rows present on sternite 3 ; a short or weak row may occasionally also be present on sternite 4; on sternite 3 is an oralmedian patch of spinules (Fig. 4). Partly transverse rows, which are broader near the front corners of the sternites and narrow or lacking medially on sternites 6 and 7, and further small patches of spinules on the oral corners of sternite 5 and near seta $V_{\text {, }}$ on segment 8 .

Lateral setae on segments 1-8: 0, 3, 3, 3, (and filamentous) $4,4,4,4-5$. Spurs on segment 8 with up to 5 fine points apically. Anal lobe fringe of filaments multiserial; number $(\mathrm{N}=13)$ of setae 115.9(105-129).

\subsection{Larva}

Length up to 14-15 mm. Ventral tubuli (Fig. 5a) of abdominal segment 8 quite straight, about $0.9-$ $1.3 \mathrm{~mm}$ long; the first pair longer than the second. No lateral tubules on abdominal segment 7. Claws of the anterior parapods smooth or very weakly serrated. Head capsule about $750 \mu \mathrm{m}$ long, quite pale, ventrally somewhat darkened. In the sensory field of the labrum $S_{\mathrm{I}}$ (Fig. 5b) 50$55 \mu \mathrm{m}$ long, with hairs on one side except apically on both sides; the most apical flattened "hair" is characteristically the strongest; $C h$ setae fine plumate. Pecten epipharyngis with 11-13 teeth. Mandibles (Fig. 6a) pale except the denticles, of which also the smallest (third) proximal may be more or less darkened or pale. Paralabials with $38-45$ 
striae, the striation about half of their breadth; the front border smooth. Hypochilum as in Fig $6 \mathrm{c}$. In the premandibles the inner (dorsal) tooth apically paler and clearly thinner than the outer (ventral).

Antennae $<190 \mu \mathrm{m}$; RO from the base of basal segment set at a distance about $1 / 3-1 / 2$ the length of this segment; proportions of the segments (1-5; Fig. 6b):

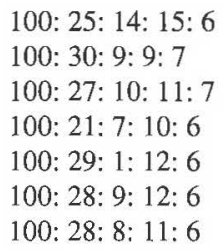

Some relations based on the measurements (compare and see abbreviations in Wülker et al. 1983: 376-377) of the antennae and hypochilum in $\mu \mathrm{m}(\mathrm{N}=9)$ :

$\begin{array}{lr}\text { Lat } & \mathrm{L}_{\mathrm{I}} \\ 64.3 & 117.6 \\ (60-69) & (110-125) \\ & \\ \mathrm{W}_{1} & \mathrm{R} / \mathrm{L}_{1} \\ 36.5 & 0.39 \\ (33-40) & (0.32-0.52) \\ & \\ \mathrm{L}_{1} / \mathrm{L}_{2} & \mathrm{~L}_{2} / \mathrm{W}_{1} \\ 3.80 & 0.88 \\ (3.29-4.81) & (0.70-1.00) \\ & \\ \mathrm{L}_{2} / \mathrm{Lat} & \mathrm{W}_{1} / \mathrm{Lat} \\ 0.48 & 0.54 \\ (0.43-0.55) & (0.49-0.56)\end{array}$

\section{Discussion}

The larva of C. clarus belongs to the "fluviatilis larval type" of the older literature corresponding to the obtusidens group sensu Wülker \& al. (1983). Larvae of this group have long, distally tapering, quite straight ventral tubuli on abdominal segment 8 , but the lateral tubules of segment 7 are not developed. Other known European species of this group are according to Wuilker \& al. (1983) C. obtusidens and C. acutiventris, including two subspecies, $C . a$. acutiventris and $C . a$. bavaricus Wülker, Ryser \& Scholl. According to Wülker \& al. (1983) the adults of C. acutiventris resemble $C$. cingulatus Meigen or $C$. venustus Staeger.

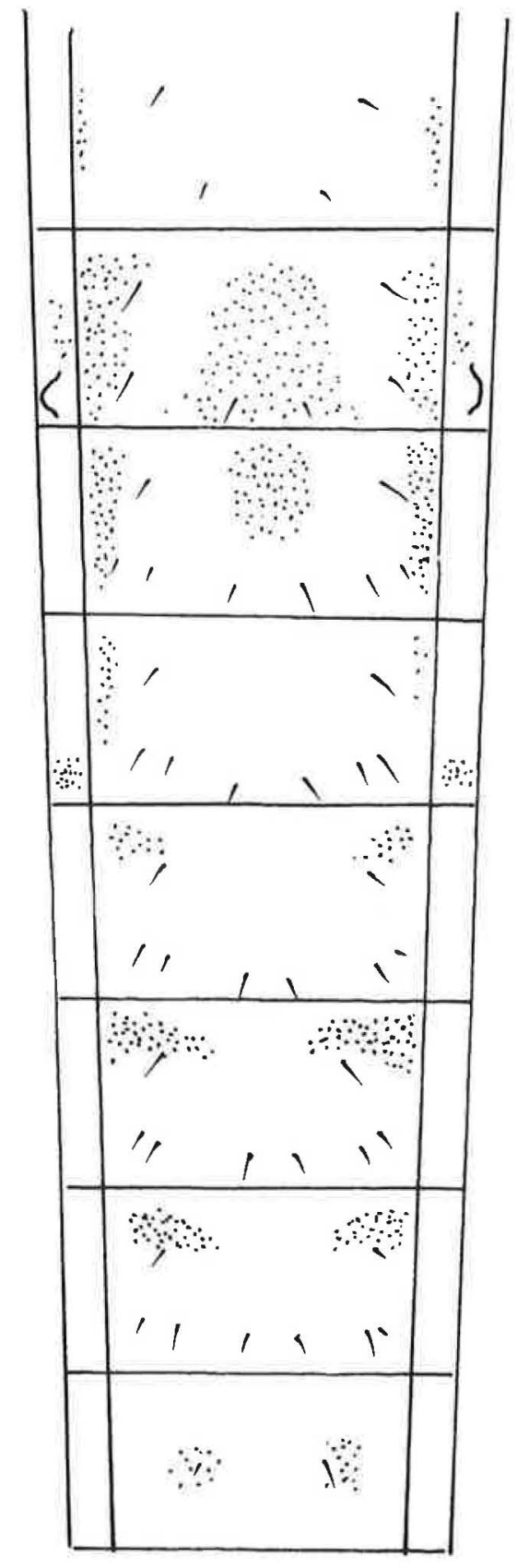

Fig. 4. Chironomus clarus Hirvenoja. Pupa: A scheme of the armament of sternites $1-8$.

Morphometrically C. clarus and C. obtusidens are similar (cf. Strenzke 1959: 16-17). In their key to European species of Chironomus, Lindeberg \& Wiederholm (1979 were able to differentiate be- 


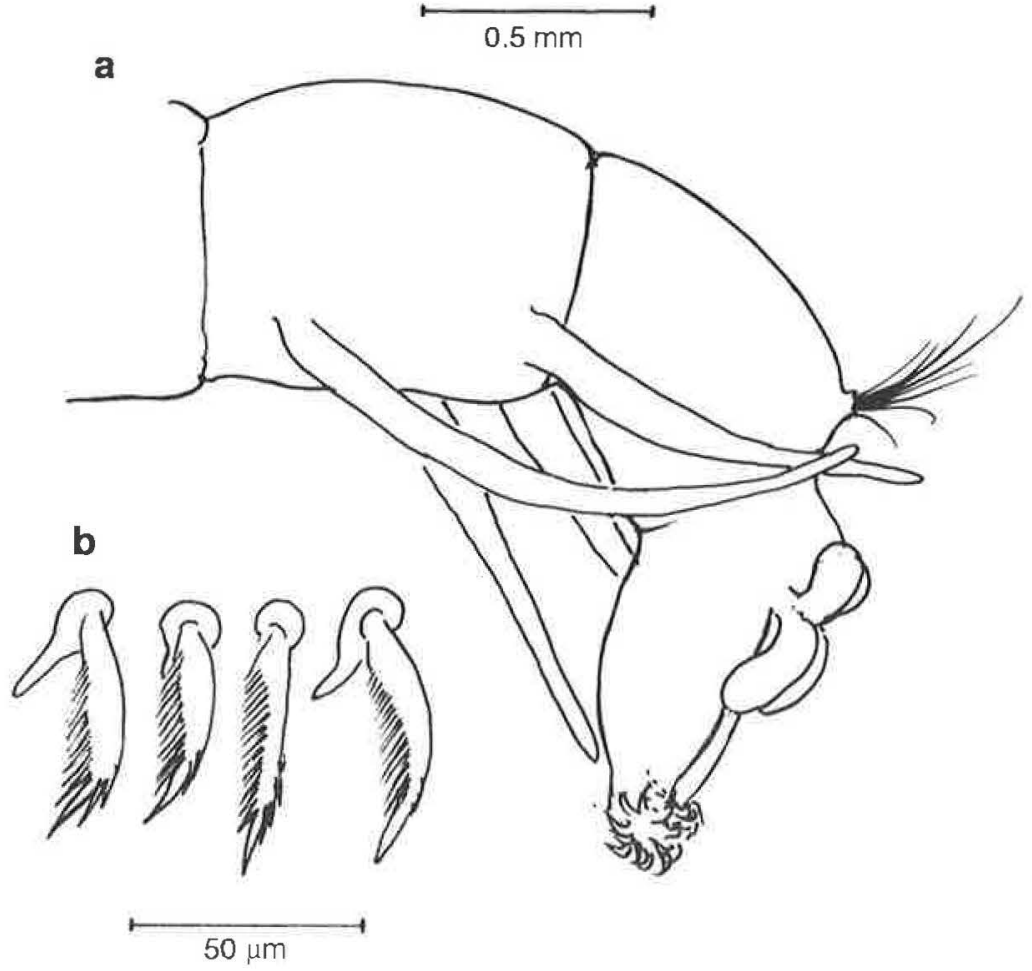

Fig. 5. Chironomus clarus Hirvenoja. a: Last segments of the larva, b: Aspects of seta $S_{1}$ in the sensory field of the labrum tween the males of $C$. clarus and $C$. obtusidens because the processus analis of the hypopygium in the latter species is pointed (Fig. 7c in Strenzke 1959). No individuals with a pointed processus analis were found in our material, and the dorsal membrane seems to be narrower in C. clarus. Pinder (1978: Fig. 142C; cf. Goetghebuer 1921 p.151 Fig. 195, 1937-1954 Fig. 89 and Shilova 1958 Fig. 43!) has illustrated the hypopygium of $C$. obtusidens, in which the anal point is not clearly pointed and another one (sub Chironomus sp. a, Fig.142D) with a very broadly rounded anal point.

C. clarus is separable, according to Lindeberg \& Wiederholm (1979, for instance from $C$. cingulatus because the anal point of $C$. cingulatus is narrower than in $C$. clarus, which partly makes a difference in the relation "width of anal point / width of appendage 1"as well as the length / width relation of the anal point proper.

The males of $C$. acutiventris and $C$. clarus may also be difficult to distinguish, because the anal point of the hypopygium seems, according to Fig. 11 in the original description of C. acutiventris, also to be quite broad, and other morphometric features are also quite similar. (Both species are distinguished by polytene chromosomes.) For instance the leg-ratio (LR) values of $C$. clarus are intermediate between the subspecies of $C$. acutiventris. Wülker et al. (1983: 738) mention, however, that in the hypopygium of $C$. acutiventris appendage 1 (or better 1a?) is not pointed.

It is probably correct to understand phylogenetically the often long, dominant apical portion of appendage 1 in Chironomini as an organ homologous to la of several Tanytarsini, mediatory structures being seen for instance in some species of Einfeldia and in some others. The reasons for some other terminological selections are the same as mentioned in Hirvenoja \& Michailova (1991b).

Morphometrically, except for $C$. obtusidens, the females of $C$. clarus resemble, for instance, females of $C$. annularius auct. (see Lindeberg \& Wiederholm 1979), but in local populations of Riihimäki the clearly different means of LR values between the females of $C$. clarus and C. riparius were useful in the determination (see also Strenzke 1959).

The pupal exuviae of $C$. clarus belong to the structural type, in which the paratergites 5 and 6 


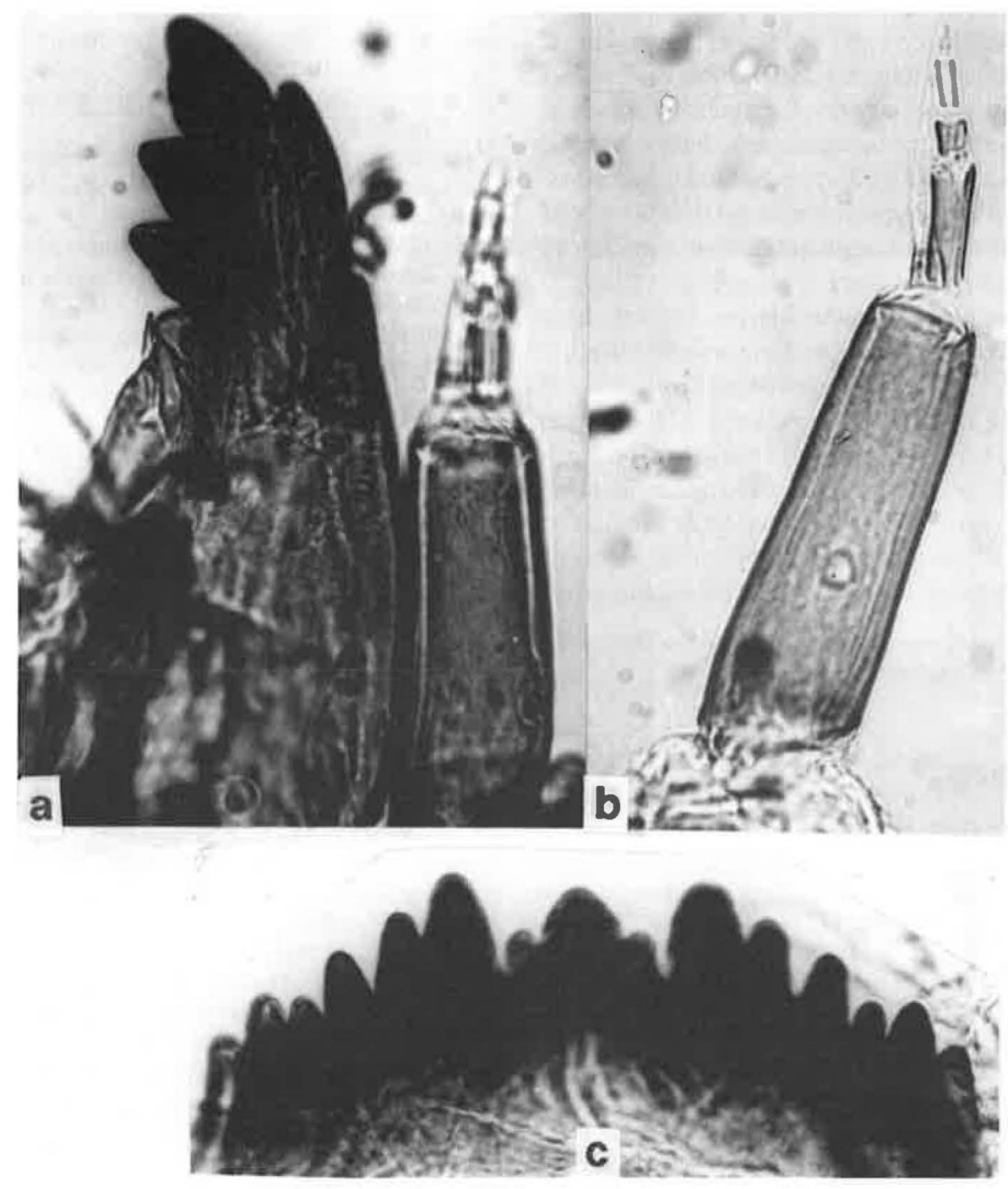

Fig. 6. Chironomus clarus Hirvenoja, Larva. a: Mandible; b: Antenna; c: Hypochilum

are spinulated, and also the pleura of segment 4 has few points (see Langton 1991: 246-251). It somewhat resembles also for instance $C$. annularius (cf. Langton 1991: 251). The tracheoles in the basal ring are, in C. clarus, however, somewhat larger, and differences exist in the shagreen of the stemites: the armament on sternite 2 is more reduced and median spinules on sternite 3 in $C$. clarus form a short patch, but in our specimens of $C$. annularius a broad longitudinal row; $C$. annularius has also longitudinal lateral rows of spinulae on sternite 4 , whereas the corresponding rows are, if present, more or less reduced or may obviously also be lacking in C. clarus.

As in $C$. obtusidens or in $C$. acutiventris (see Wülker et al. 1983), the dentation of the hypochilum of the C. clarus larva is also of a type quite similar to that known as the "anthracinus larval type"with its small fifth lateral tooth. This type occurs in several species. Most similar larvae seem to be on the basis of the given morphometric features $C$. clarus and C. acutiventris bavaricus.

The data reported on the karyotype indicate that C. clarus and $C$. obtusidens are homosequental 
sister species (if not even synonyms). They have one and the same band sequences. However, $C$. obtusidens has thinner bands than those of $C$. clarus. This situation is known in the genus Chironomus and has been found for example in the species pairs C. riparius C. piger (Keyl \& Strenzke 1956). According to karyotype, this species should be combined with C. obtusidens and C. acutiventris in the obtusidens group sensu Wülker et al. (1983). C. clarus is a monomorphous species. The sex-determining inversion which has been observed in arm $\mathrm{F}$ of $C$. obtusidens has not been found in our material.

Because of the great similarity of the species discussed here, further careful studies are desirable to confirm the constancy of the characters. Ecologically, C. clarus (cf. also Hirvenoja \& Michailova 1991a: 318) prefers lotic biotopes or lacustrine littoral as do the other species of the obtusidens group.

Acknowledgements: We are indebted to Dr. Carolyn Norris for the English language corrections.

\section{References}

Brundin, L. 1956: Die Bodenfaunistischen Seetypen und ihre Anwendbar auf die Südhalbkugel. Zugleich eine Theorie der Productionsbiologischen Bedeutung der glazialen Erosion. - Inst. Freshwater Res. Drottningholm Rep. 37:186-235

Fittkau, E.-J. 1962: Die Tanypodinae (Diptera, Chironomidae). Die Tribus Anatopyniini, Macropelopiini und Pentaneuriini. - Abh. Larvalsyst. Insekten 6:1-453

Goetghebuer, M. 1921: Chironomides de Belgique et spécialement de la zone des Flandres. - Mém. Mus. R. Hist. Nat. Belg. 8:1-211

- 1937-1954: Tendipedidae (Chironomidae). b) Subfamilie Tendipedinae (Chironominae). A. Die Imagines. - In Lindner, E. (ed.): Die Fliegen der palaearktischen Region 13c:1-138

Hirvenoja, M. 1962a: Zur Kenntnis der Gattung Chironomus (Dipt., Chironomidae). - Ann. Entomol. Fennici 28:85-88

- 1962b: Ein Vergleich der Culiciden-Fauna einiger südund nordfinnischen Schmelzwasserlachen. - Ann. Entomol. Fennici 28:97-107

Hirvenoja, M. \& Michailova, P. 1991a: Chironomus melanotus Keyl and its taxonomical and ecological relations to $\mathrm{C}$. riihimakiensis Wülker. - Spixiana 14:309-320

- 1991b: The caryotype, morphology and ecology of Glyptotendipes aequalis Kieffer (Diptera, Chirono- midae). - Entomol. Fennica 2:87-96

Keyl, H. 1960: Die cytologische Diagnostik der Chironomiden. II Diagnosen der Geschwisterarten Chironomus n. sp. und C. uliginosus n. sp. - Arch. Hydrobiol. 57:187-195

- 1962: Chromosomenevolution bei Chironomus. Chromosomenumbauten und phylogenetische Beziehungen der Arten. - Chromosoma 13:496-541

Keyl, H. \& Strenzke, K. 1956: Taxonomie und Cytologie von zwei Subspecies der Art Chironomus thummi. Zeitschr. Naturforsch. 11 Teil B:727-735

Kiknadze, I. I. 1987: Chromosomal polymorphism in natural populations of the plumosus group in west Siberia (Diptera, Chironomidae). - Entomol. Scand., Suppl. 29:113-121

Langton, P. H. 1991: A key to pupal exuviae of West Palaearctic Chironomidae. - Mimeogr. 386 pp.

- 1994: Adhesion marks on the abdomen of pupal Chironomidae (Diptera). - Br. J. Entomol. Nat. Hist. 7:89-91

Lindeberg, B. \& Wiederholm, T. 1979: Notes on the taxonomy of European species of Chironomus (Diptera: Chironomidae). - Entomol. Scand., Suppl. 10:99-116

Maximova, F. L. 1976: The karyotype of Chironomus plumosus L. from Ist-Ishova wild population of Leningrad region. - Tsitologia 23:1264-1269

Michailova, P. 1989: The polytene chromosomes and their significance to the systematics of the family Chironomidae, Diptera. - Acta Zool. Fennica 186:1-107

Petrova, N. \& Michailova, P. 1986: The populationkaryological studies of some Chironomidae species (Diptera, Chironomidae). - Cytologia 7:727-734

Pinder, L. C. V. 1978: A key to adult males of British Chironomidae (Diptera) the non-biting midges, Vol. 2. Illustrations of the hypopygia. - Freshw. Biol. Assoc. Sci. Publ. 37: Figs 77-189

Shilova, A. I. 1958: Zur Systematik der Gattung Tendipes Mg. (Diptera, Tendipedidae). - Entomol. Obosr. 37:434-451 (in Russian, German summary with keys for larvae and pupae).

Strenzke, K. 1959: Revision der Gattung Chironomus Meig. 1. Die Imagines von 15 norddeutschen Arten und Unterarten. - Arch. Hydrobiol. 56:1-42

Thienemann, A. 1944: Bestimmungstabellen für die bis jetzt bekannten Larven und Puppen der Orthocladiinen (Diptera, Chironomidae). - Arch. Hydrobiol. 39:551664

Wülker, W. 1980: Basic patterns in the chromosome evolution of the genus Chironomus (Diptera). - Z. Zool. Syst. Evolutionsforsch. 18:112-123

Wülker, W., Ryser, H. M. \& Scholl, A. 1983: Revision der Gattung Chironomus Meigen (Diptera). VIII. Arten mit Larven des fluviatilis-Typs (obtusidens-Gruppe): C. acutiventris n. sp. und C. obtusidens Goetgh. Rev. Suisse Zool. 90:725-745 